\title{
TESTIMONY
}

\section{Personal Collection Development}

This column serves as a debriefing of the events that led me to the borderline-traumatic deselection of three library collections. Within five years, my dad passed away, my son was born, and I was hired in my first professional university library position. My father's passing forced my family to consider the fate of the stamp collection he had amassed over fifty years. A few years later, the coin flipped, and new fatherhood compelled me to question the content of my personal book and media collection. These two deeply personal auras of thought were lent a professional perspective as the university library I was newly hired into began its first ever comprehensive weeding. What follows are the brief histories behind these three collections.

The university I now work for was founded in 1922 as a normal school (a teachers' college) in the middle of farmland. Its library began on the stage of the local high school with a dictionary and a Bible. The university remains surrounded by farmland, but now as a fully-accredited multidisciplinary college with several advanced degree programs. The library has modernized and the collection has grown well beyond a handful of monographs. However, with no systematic weeding in 90 years, the collection was, in farmer parlance, going to seed.

As luck would have it, when the library finally did embark on a weeding project, it was just as I was hired. The process walked a well-trod path likely familiar to readers of this column. Librarians like myself made use of reports to scour our, hrm, mature collection. We asked boilerplate questions like: Is this information out of date? Does this support the current curriculum? Has this ever been used?

But all the practical doing of this, to me, the newly-hired interim Research and Instruction Librarian, was daunting. I would have a hand in the regeneration of a nearly century-old collection, created by librarians with years of experience well beyond my own. While I had spent many hours as an undergrad here, I was a philosophy and English major who seldom charted the rest of the call number ranges. While I was attempting to learn what resources students and faculty might use, I was simultaneously making educated guesses about what I prayed they wouldn't miss.

It helped that the departments I represent were no longer looking as closely at this print collection. It also helped that I already had experience letting a well-considered, well-loved collection go.

My father was "struck down" (in his good-natured telling of it) with the polio virus in first grade. In the years leading up to this, philately had been popularized by President Franklin Delano Roosevelt, a fellow American similarly struck down. My father's Aunt Adele gifted my father his first stamp album during his year of hospital bed confinement. Where Aunt Adele and FDR gave him a lifelong hobby, my dad gave me a childhood home that resembled a special collections museum.

Although my immediate family enjoyed suggesting he was an insatiable hoarder, my dad was, in fact, quite selective. He assembled complete stamp sets from most countries with a postal system, and he had a penchant for Civil War and Depression-era Kentucky memorabilia. I distinctly recall him showing me a beautifully-penned letter from a Civil War soldier to President Lincoln, which was one in a series of choice pieces deployed in his failed bid to shepherd me into the (dusty) fold.

There is a shadow box in my mom's kitchen framing a humorously large blue ribbon from one of the occasions my dad proudly took home the "big" antiques prize at the Kentucky State Fair. At his funeral in 2010, I was given a book on Louisville's historic Brownsboro Road by its author with my father's name highlighted in the acknowledgements. I can't recall if this was before or after a very classy antiques dealer slipped me his business card. All this to say, my own appreciation withstanding, my dad was not a junk collector.

Visiting home and walking past the 'stamp room' had been a comfort since his death. All those green, red, and blue buckram album spines with gold-lettered names of continents staring back at me as they had my entire life, as they had stared at my father for decades. But without my father, those albums weren't receiving their deserved attention. He conscientiously made it clear throughout his life these items should be with real collectors. He did not collect like a hoarder, and neither would we. So, sometime after my father's passing, my family made the difficult decision to entrust a professional dealer to take nearly the entire collection to auction.

\footnotetext{
"Abridged and edited with permission by Leslie Engelson. Full article available from: Biblio-Notes 67 (Spring 2016). http://www.ala.org/ acrl/sites/ala.org.acrl/files/content/aboutacrl/directoryofleadership/sections/les/biblio-notes/biblio-notes-2016-issue-67.pdf
} 
For my home library, my wife bought me a set of bookcases in 2011 which covered every wall of my office that was not a door or window. I filled every inch of these 27 shelves with books, movies, and records. Even more spilled into the living room, random boxes, and into my mom's garage two hundred miles away. Call this seeming excess the product of a childhood spent indoors and of working in video retail places. But at the end of 2014, a year after my son's birth, something in me changed. My approach toward collecting went from completist to essentialist. Here in 2016, the living room, my mom's garage, and nearly half the shelves in my home office are empty.

Some of my non-canonical reading bolstered my position to discard and to even view deselection as creative selection. For instance, the new world of bills heralded in with the birth of my son, inspired a reluctant Google search for Dave Ramsey, the money guru who champions debt simplicity. By selling the apparently non-essential portion of my collection, I was financing new purchases relatively guilt-free. I joyfully held the Kool-Aid cup served with Marie Kondo's The Life Changing Magic of Tidying Up. And I was very taken with Kanye West's paraphrasing of Antoine de Saint-Exupéry in Rolling Stone (2013): "a design is the point where you can't take anything else away."

But what really inspired this farewell to armfuls of paper and plastic was a little boy. Collecting had been for myself, but now there was an impressionable mind in the house, spending time in my office, observing the interests his father cultivated. Keeping copies of every book I read was not achieving this picture. Besides, if a complete reading history is ever sought, I have a Goodreads account.

Cutting away the fat, so to speak, reveals a more robust set of priorities, not only of taste, but of practical living. What one chooses to devote time, space, and money toward is a meaningful showing. A university library transforming untouched manuscripts into student space ably demonstrates a shift of values. As much as my son appreciates his toys, he easily parts with them as he outgrows them. The bulk of what I have is not rare, not like my father's archive. There should be little remorse when I shed a box of DVDs and reclaim that space with a set of Curious George books and a sippy cup. What I've learned from my dad, my son, and my work is that part of growing is letting things go.

Submitted by

Arthur (AJ) Boston, Scholarly Communications Librarian

Waterfield Library, Murray State University orcid.org/0000-0001-8590-4663 